\title{
Synthesis of 1-Substituted-4-(Pyridin-4-yl) [1,2,4] Triazolo [4,3-a] Quinazolin-5(4H)-ones as a New Class of H1- Antihistaminic Agents
}

\author{
M Gobinath ${ }^{1 *}$, N Subramanian², V Alagarsamy ${ }^{3}$, S Nivedhitha ${ }^{1}$ and V Raja \\ Solomon ${ }^{3}$ \\ ${ }^{1}$ Department of Pharmaceutical Chemistry, Ratnam Institute of Pharmacy, Pidathapolur Village, Nellore - 524346 , \\ ${ }^{2}$ Department of Pharmaceutical Technology, Anna University of Technology, Tiruchirappalli - $620024,{ }^{3}$ Medicinal Chemistry \\ Research Laboratory, MNR College of Pharmacy, Sangareddy, Gr. Hyderabad-502 294, India
}

*For correspondence: Email: drvalagarsamy@gmail.com; Tel: +91-9246425702, 8008100003

\begin{abstract}
Purpose: To synthesize a new series of 1-substituted-4-(pyridin-4-yl) [1,2,4] triazolo[4,3-a]quinazolin$5(4 H)$-ones and evaluate them for $\mathrm{H} 1$-antihistaminic activity with negligible side effects in guinea pigs. Methods: The synthesized compounds were characterized by Infrared spectroscopy (IR), proton nuclear magnetic resonance ( $\left.{ }^{1} H-N M R\right)$ and mass spectrometry (MS) data. The purity of the compounds was determined by elemental analysis. The antihistaminic activity of the compounds was evaluated in guinea pigs by histamine-induced bronchoconstriction method.

Results: Among the series, 1-methyl-4-(pyridin-4-yl) [1,2,4] triazolo [4,3-a] quinazolin-5(4H)-one (S5) was the most potent with $72.85 \%$ protection and its potency was comparable to that of the reference, chlorpheniramine maleate (70.09\%). Interestingly, the sedative property of compound S5 was negligible (5.09\%) when compared to chlorpheniramine maleate (29.58 \%).

Conclusion: Compound S5 can serve as a lead molecule for further development into a new class of H1-antihistaminic agents.
\end{abstract}

Keywords: Quinazolin-5-ones, Antihistaminic activity, Histamine, Bronchoconstriction

\begin{abstract}
Tropical Journal of Pharmaceutical Research is indexed by Science Citation Index (SciSearch), Scopus, International Pharmaceutical Abstract, Chemical Abstracts, Embase, Index Copernicus, EBSCO, African Index Medicus, JournalSeek, Journal Citation Reports/Science Edition, Directory of Open Access Journals (DOAJ), African Journal Online, Bioline International, Open-J-Gate and Pharmacy Abstracts
\end{abstract}

\section{INTRODUCTION}

Heterocyclic synthesis has emerged as a powerful technique for generating new chemical entities useful for drug discovery [1]. Heterocyclic compounds provide scaffolds on which pharmacophores can be arranged to obtain potent and selective drugs [2]. The first generation anti-histamines penetrate the blood brain barrier and also possess anticholinergic properties and this has led to the development of a second generation $\mathrm{H}_{1}$-antagonists such as terfenadine, cetirizine and astemizole [3]. A common feature of first generation compounds includes two aryl or heteroaryl rings linked to an aliphatic tertiary amine via the side chain (e.g., diphenhydramine and pheniramine), the secondgeneration compounds (terfenadine and cetirizine) also contain many of the structural features of first generation compounds [4].

The real breakthrough of non-sedative antihistamines came in the early 1980s when the discovery of modern antihistamines, was found to exhibit potent antihistaminic activity without sleep-inducing effect [5]. Condensed 
heterocycles containing new generation of $\mathrm{H}_{1-}$ antihistamines [e.g. Ioratadine, azelastine and flazelastine] that does not possess the above mentioned pharmacophore for $\mathrm{H}_{1}$-antihistamines gave way for the discovery of many novel antihistamines temelastine and mangostin $[6,7]$. Quinazolinones are associated with a wide range of biological and pharmacological activities such as analgesic [8], anti-inflammatory [9], antifungal $[10,11]$, antiviral [12] and antihistaminic activities $[13,14]$.

The present work is an extension of our ongoing efforts geared towards the development and identification of new quinazolinone derived antihistaminics; thus we aimed to synthesize a series of 1-substituted-4-(pyridin-4-yl) $\quad[1,2,4]$ triazolo[4,3-a]quinazolin-5(4H)-ones.

synthesized compounds were tested for their in vivo $\mathrm{H}_{1}$-antihistaminic activity in conscious guinea pigs. As sedation is one of the major side effects associated with antihistamines, the test compounds were also evaluated for their sedative potentials.

\section{EXPERIMENTAL}

Starting material for the synthesis, reagents and solvents were of analytical grade and were purchased from Aldrich Chemical Co., Merck Chemical Co., and dried in a desiccator when necessary. Histamine (Sigma Chemicals, USA), aminophylline (Unichem, Mumbai), chlorpheniramine maleate (Hoechst, Mumbai, India) and cetirizine (Sun Pharma, Mumbai, India) were procured for the present biological study. Melting points were determined using silicon oil bath type melting point apparatus (Veego) and are uncorrected. NMR spectra, using Varian $300 \mathrm{MHz}$, were recorded in $\mathrm{CDCl}_{3}$ (unless specified) with TMS as internal reference (chemical shift in $\delta, \mathrm{ppm}$ ). IR spectra (using Shimadzu FT-IR, 8300) in $\mathrm{KBr}(v$ max in $\mathrm{cm}-1)$ and mass spectra at $70 \mathrm{eV}$ on a MASPEC msw 9629 instrument were also obtained for the compounds. Elemental analysis was performed using Carlo Erba apparatus. Silica gel G (E. Merck) was used for TLC with iodine vapour used for exposure of the TLC plates. Anhydrous sodium sulphate (S.D. Fine Chemicals, Mumbai, India) was used as drying agent. Synthetic route depicted in Scheme 1 outline the chemistry part of the present work.

\section{Synthesis of 3-(pyridin-4-yl)-2-thioxo-2,3- dihydroquinazolin-4(1H)-one (S1)}

A solution of the 4-amino pyridine $(0.02 \mathrm{~mol})$ in dimethyl sulfoxide $(10 \mathrm{~mL})$ was stirred vigorously. To this carbon disulphide $(1.6 \mathrm{~mL})$ and aqueous sodium hydroxide (1.2 mL, 20 molar) was added drop by drop during $30 \mathrm{~min}$ with stirring. Dimethyl sulphate $(2.5 \mathrm{~g}, 0.02 \mathrm{~mol})$ was added gradually with stirring by keeping the reaction mixture in freezing mixture for $2 \mathrm{~h}$. The reaction mixture was then poured into ice water. The solid obtained was filtered, washed with water, dried and recrystallized from ethanol.

Methyl anthranilate $(1.5 \mathrm{~g}, 0.01 \mathrm{~mol})$ and the above prepared $\mathrm{N}$-(pyridin-4-yl)-methyl dithiocarbamic acid $(0.01 \mathrm{~mol})$, were dissolved in ethanol $(20 \mathrm{~mL})$. To this anhydrous potassium carbonate $(100 \mathrm{mg})$ was added and refluxed for $18 \mathrm{~h}$. The reaction mixture was cooled in ice and the solid separated was filtered and purified by dissolving in $10 \%$ alcoholic sodium hydroxide solution and re-precipitated by treating with dilute hydrocholoric acid. The solid obtained was filtered, washed with water, dried and recrystallized from ethanol.

\section{Synthesis of 2-(methylthio)-3-(pyridin-4- yl)quinazolin-4(3H)-one (S2)}

The 3-(pyridin-4-yl)-2-thioxo-quinazolin-4(1H)one (S1) (0.01 mol) was dissolved in $20 \mathrm{~mL}$ of 2 $\%$ alcoholic sodium hydroxide solution. To this dimethyl sulphate $(1.26 \mathrm{~g}, 0.01 \mathrm{~mol})$ was added drop by drop with stirring and stirring was continued for $1 \mathrm{~h}$ after completion of addition. The reaction mixture was then poured into ice water. The solid obtained was filtered, washed with water, dried and recrystallized from ethanolchloroform (75:25) mixture.

\section{Synthesis of 2-hydrazinyl-3-(pyridin-4- yl)quinazolin-4(3H)-one (S3)}

The 2-methylthio-3-(pyridin-4-yl) quinazolin$4(3 \mathrm{H})$-one (S2) $(0.01 \mathrm{~mol})$ was dissolved in ethanol $(25 \mathrm{~mL})$. To this hydrazine hydrate $(5.0$ $\mathrm{g}, 0.1 \mathrm{~mol}$ ) and anhydrous potassium carbonate $(100 \mathrm{mg})$ was added and refluxed for $23 \mathrm{~h}$. The reaction mixture was cooled and poured into icewater. The solid obtained was filtered, washed with water, dried and recrystallized from chloroform-benzene (50:50) mixture.

Synthesis of 4-(pyridin-4-yl)$[1,2,4]$ triazolo[4,3-a]quinazolin-5(4H)-one (S4)

The 2-hydrazino-3-(pyridin-4-yl) quinazolin4(3H)-one (S3) (0.01 mol) and formic acid (15 


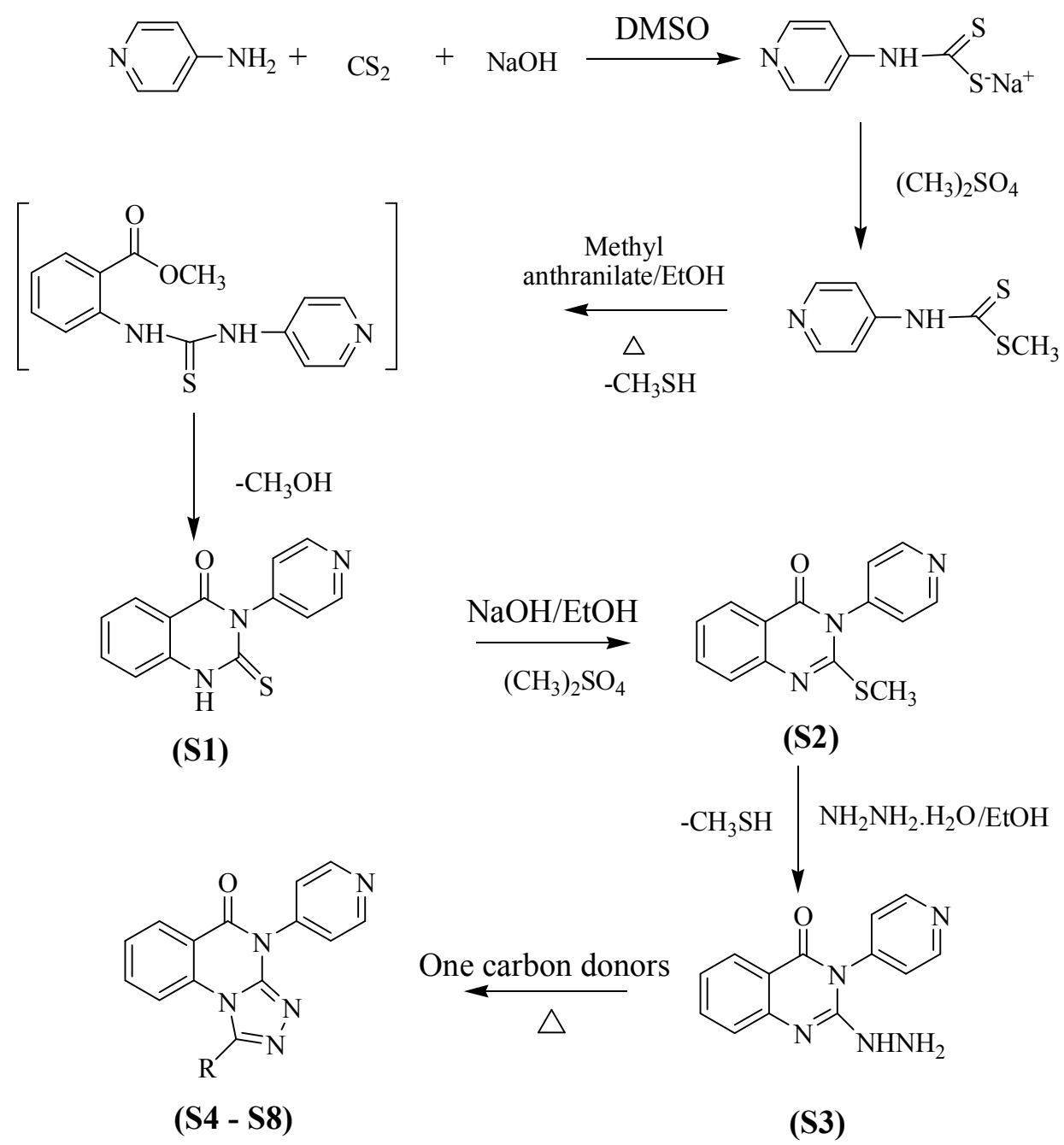

S4 $\mathrm{R}=\mathrm{H}$

S5 $\mathrm{R}=\mathrm{CH}_{3}$

S6 $\mathrm{R}=\mathrm{CH}_{2} \mathrm{CH}_{3}$

S7 $\mathrm{R}=\mathrm{CH}_{2} \mathrm{CH}_{2} \mathrm{CH}_{3}$

S8 $\mathrm{R}=\mathrm{CH}_{2} \mathrm{Cl}$

Scheme 1: Synthetic protocol of 1-substituted-4-(pyridine-4-yl) $[1,2,4]$ triazolo $[4,3-a]$ quinazolin-5(4H)-ones

$\mathrm{mL}$ ) was taken in a round bottom flask and refluxed for $29 \mathrm{~h}$, cooled and poured into ice water. The solid obtained was filtered, washed with water, dried and recrystallized from chloroform-ethanol $(75: 25)$ mixture.

\section{Synthesis of 1-methyl-4-(pyridin-4-yl)-} $[1,2,4]$ triazolo[4,3-a]quinazolin-5(4H)-one (S5)

The 2-hydrazino-3-(pyridin-4-yl) quinazolin4(3H)-one (S3) $(0.01 \mathrm{~mol})$ and acetic acid (15 $\mathrm{mL}$ ) was taken in a round bottom flask and refluxed for $29 \mathrm{~h}$, cooled and poured into ice water. The solid obtained was filtered, washed with water, dried and recrystallized from ethanol.

\section{Synthesis of 1-ethyl-4-(pyridin-4-yl)-}

\section{$[1,2,4]$ triazolo[4,3-a]quinazolin-5(4H)-one (S6)}

The 2-hydrazino-3-(pyridin-4-yl) quinazolin4(3H)-one (S3) (0.01 mol) and propionic acid (15 $\mathrm{mL}$ ) were taken in a round bottom flask and refluxed for $25 \mathrm{~h}$, cooled and poured into ice water. The solid obtained was filtered, washed with water, dried and recrystallized from ethanol.

Synthesis of 1-propyl-4-(pyridin-4-yl)$[1,2,4]$ triazolo[4,3-a]quinazolin-5(4H)-one (S7)

The 2-hydrazino-3-(pyridin-4-yl) quinazolin4(3H)-one (S3) (0.01 mol) and butyric acid (15 $\mathrm{mL}$ ) was taken in a round bottom flask and refluxed for $23 \mathrm{~h}$, cooled and poured into ice water. The solid obtained was filtered, washed with water, dried and recrystallized from ethanol.

\section{Synthesis of 1-(chloromethyl)-4-(pyridin-4-yl)- $[1,2,4]$ triazolo[4,3-a]quinazolin-5(4H)-one (S8)}

The 2-hydrazino-3-(pyridin-4-yl) quinazolin$4(3 \mathrm{H})$-one (S3) $(0.01 \mathrm{~mol})$ and chloroacetyl chloride $(0.01 \mathrm{~mol})$ in glacial acetic acid $(15 \mathrm{~mL})$ was taken in a round bottom flask and refluxed for $13 \mathrm{~h}$, cooled and poured into ice water. The 
solid obtained was filtered, washed with water, dried and recrystallized from chloroform-ethanol (75:25) mixture.

\section{Pharmacological studies}

The synthesized compounds were evaluated for antihistaminic and sedative-hypnotic activities. The animals were maintained in colony cages at $25 \pm 2{ }^{\circ} \mathrm{C}$, relative humidity of $45-55 \%$, under a $12 \mathrm{~h}$ light and dark cycle; they were fed standard animal feed. All the animals were acclimatized for a week before use [18]. The experimental protocol was duly approved by the institutional animal ethical committee (IAEC, F. No.25/559/2010-AWD) constituted by Committee for the Purpose of Control and Supervision of Experimental Animals (CPCSEA), Ministry of Environment and Forest, New Delhi, India (IAEC, F. No.25/559/2010-AWD) [18].

\section{Antihistaminic activity}

A modification of the technique of Van Arman was adopted to determine the antihistaminic potential of the synthesized compounds [19]. Male Dunkin Hartley guinea pigs (250 - $300 \mathrm{~g}$ ) were fasted for $12 \mathrm{~h}$. Six animals were taken in each group. The test compounds, was administered orally at a dose of $10 \mathrm{mg} / \mathrm{kg}$ in $1 \%$ carboxymethyl cellulose (CMC) and challenged with histamine aerosol $(0.2 \%$ aqueous solution of histamine acid chloride $3 \mathrm{~mL}$ ) in a vaponephrin pocket nebulizer sprayed into a closed transparent cage. The respiratory status reflecting the increasing degree of bronchoconstriction was recorded. The time for onset of convulsions (preconvulsion) was recorded. Animals remaining stable for more than $6 \mathrm{~min}$ were considered protected against histamine-induced bronchospasm. An intraperitoneal injection of chlorpheniramine maleate (Hoechst, Mumbai, India) at a dose of $25 \mathrm{mg} / \mathrm{kg}$ was given for the recovery of the test animals. The mean preconvulsion time of animals, treated with the test compounds was compared to control and is expressed in percent protection as in Eq 1 (see Table 1).

Protection $(\%)=\left\{1-\left(\mathrm{T}_{1} / \mathrm{T}_{2}\right)\right\} 100$

where $T_{1}$ and $T_{2}$ are preconvulsive time of control and test compound, respectively.

The activity of the test compounds was compared with the standard antihistamine chlorpheniramine maleate.

\section{Sedative-hypnotic activity}

Sedative-hypnotic activity was determined by measuring the reduction in locomotor activity using actophotometer $[19,20]$. Swiss albino mice were chosen as test animals in a group of 6 . Basal activity score was taken and then compounds S4-S8 and standard chlorpheniramine maleate were administered orally at the dose of $5 \mathrm{mg} / \mathrm{kg}$ in $1 \% \mathrm{CMC}$. Scores were recorded at 1,2 and $3 \mathrm{~h}$ after the drug administration. Student-t-test was performed to ascertain the significance of the exhibited activity. Percent reduction in locomotor activity was calculated as in Eq 2.

Reduction in motor activity $(\%)=\{(\mathrm{A}-\mathrm{B}) / \mathrm{A}\} 100 \ldots \ldots(2)$

where $A$ and $B$ are the basal and post-drug treatment scores.

\section{Statistical analysis}

Statistical analysis of the pharmacological data was performed by one-way ANOVA followed by Dunnett's test. In all cases, significance level of the mean of individual groups was performed and compared with control. A significance level of $p<0.5$ indicated significance in all cases.

\section{RESULTS}

The key intermediate 3-(pyridin-4-yl)-2-thioxo2,3-dihydroquinazolin-4(1H)-one (S1), was prepared by reacting 4-amino pyridine with carbon disulphide and sodium hydroxide in dimethyl sulphoxide to give sodium dithiocarbamate, which was methylated with dimethyl sulfate to afford the dithiocarbamic acid methyl ester, which upon reflux with methyl anthranilate in ethanol yielded the desired 3(pyridin-4-yl)-2-thioxo-2,3-dihydroquinazolin$4(1 \mathrm{H})$-one $(\mathrm{S} 1)$ via the thiourea intermediate in good yield (85\%). The product obtained was cyclic and not an open chain thiourea.

The 2-(methylthio)-3-(pyridine-4-yl) quinazolin$4(3 \mathrm{H})$-one $\mathrm{S} 2$ was obtained by dissolving $\mathrm{S} 1$ in 2 $\%$ alcoholic sodium hydroxide solution and methylating with dimethyl sulphate with stirring at room temperature. Nucleophilic displacement of methylthio group of S2 with hydrazine hydrate was carried out using ethanol as solvent to afford 2-hydrazinyl-3-(pyridine-4-yl)-quinazolin-4(3H)one S3.

The long duration of reaction (23 $\mathrm{h}$ ) required might be due to the presence of bulky aromatic ring at position 3 , which might have reduced the 
reactivity of quinazoline ring system at $\mathrm{C}-2$ position. The title compounds S4-S8 were obtained in fair to good yields through the cyclization of S3 with a variety of one carbon donors such as formic acid, acetic acid, propionic acid, butyric acid and chloroacetyl chloride at reflux. The 1H NMR spectrum of S4-S8 showed the absence of $\mathrm{NH}$ and $\mathrm{NH} 2$ signals.

\section{3-(pyridin-4-yl)-2-thioxo-2,3- dihydroquinazolin-4(1H)-one (S1)}

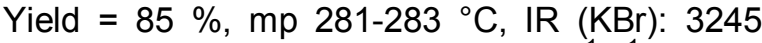
$(\mathrm{NH}), 1663(\mathrm{C}=\mathrm{O}), 1228(\mathrm{C}=\mathrm{S}) \mathrm{cm}^{-1},{ }^{1} \mathrm{H}$ NMR $\left(500 \mathrm{MHz}, \mathrm{CDCl}_{3}\right): \delta 6.42-6.44(\mathrm{~d}, \mathrm{~J}=7.5 \mathrm{~Hz}$, $2 \mathrm{H}, \operatorname{Ar}-H), 7.18-7.86(\mathrm{~m}, 4 \mathrm{H}, \mathrm{Ar}-\mathrm{H}),(\mathrm{d}, \mathrm{J}=7.5$ $\mathrm{Hz}, 2 \mathrm{H}$, Ar- $H$ ), 8.42-8.44 (d, J = 8.0 Hz, 2H, Ar$H), 10.88(\mathrm{br} \mathrm{s}, 1 \mathrm{H}, \mathrm{NH})$, Mass $(\mathrm{m} / \mathrm{z}): 255\left[\mathrm{M}^{+}\right]$.

\section{2-(methylthio)-3-(pyridin-4-yl)quinazolin- $4(3 H)$-one (S2)}

Yield: $86 \%$, mp: $153-154{ }^{\circ} \mathrm{C}, \mathrm{IR}(\mathrm{KBr}): 1681$ $(\mathrm{C}=\mathrm{O}) \mathrm{cm}^{-1},{ }^{1} \mathrm{H}$ NMR $\left(500 \mathrm{MHz}, \mathrm{CDCl}_{3}\right): \delta 2.57$ (s, 3H, $\left.\mathrm{SCH}_{3}\right), 6.41-6.43(\mathrm{~d}, \mathrm{~J}=7.5 \mathrm{~Hz}, 2 \mathrm{H}, \mathrm{Ar}-$ $H$ ), 7.26-7.72 (m, 4H, Ar-H), 8.43-8.45 (d, J = 8.0 $\mathrm{Hz}, 2 \mathrm{H}, \operatorname{Ar}-H)$, Mass (m/z): $269\left[\mathrm{M}^{+}\right]$.

\section{2-hydrazinyl-3-(pyridin-4-yl)quinazolin-4(3H)- one (S3)}

Yield: $82 \%$, mp 219-221 ${ }^{\circ} \mathrm{C}$, IR (KBr): 3334, $3203\left(\mathrm{NHNH}_{2}\right), 1673(\mathrm{C}=\mathrm{O}) \mathrm{cm}^{-1},{ }^{1} \mathrm{H}$ NMR $(500$ $\mathrm{MHz}, \mathrm{CDCl}_{3}$ ): $\delta 4.72\left(\mathrm{br} \mathrm{s}, 2 \mathrm{H}, \mathrm{NH}_{2}\right.$ ), 6.40-6.42 (d, J = 7.5 Hz, 2H, Ar- $H$ ), 7.29-7.81 (m, 4H, Ar$H$ ), 8.41-8.43 (d, J = 8.0 Hz, 2H, Ar-H), 9.28 (br $\mathrm{s}, 1 \mathrm{H}, \mathrm{NH})$, Mass $(\mathrm{m} / \mathrm{z}): 253\left[\mathrm{M}^{+}\right]$.

\section{4-(pyridin-4-yl)-[1,2,4]triazolo[4,3- a]quinazolin-5(4H)-one (S4)}

Yield: $85 \%$, mp. 236-237 ${ }^{\circ} \mathrm{C}, \mathrm{IR}$ (KBr): 1669 $(\mathrm{C}=\mathrm{O}), 1623(\mathrm{C}=\mathrm{N}) \mathrm{cm}^{-1},{ }^{1} \mathrm{H}$ NMR $(500 \mathrm{MHz}$, $\left.\mathrm{CDCl}_{3}\right): \delta 6.40-6.42(\mathrm{~d}, \mathrm{~J}=7.0 \mathrm{~Hz}, 2 \mathrm{H}, \mathrm{Ar}-\mathrm{H})$, 7.25-7.70 (m, 4H, Ar- $H), 8.41-8.43(\mathrm{~d}, \mathrm{~J}=7.5 \mathrm{~Hz}$, $2 \mathrm{H}, \operatorname{Ar}-H), 8.92(\mathrm{~s}, 1 \mathrm{H}, \operatorname{Ar}-H)$; Mass $(\mathrm{m} / \mathrm{z}): 263$ $\left[\mathrm{M}^{+}\right]$.

\section{1-methyl-4-(pyridin-4-yl)-[1,2,4]triazolo[4,3- a]quinazolin-5(4H)-one (S5)}

Yield: $82 \%$, mp. $251-253{ }^{\circ} \mathrm{C}$, IR (KBr): 1686 $(\mathrm{C}=\mathrm{O}), 1607(\mathrm{C}=\mathrm{N}) \mathrm{cm}^{-1},{ }_{1}^{1} \mathrm{H}$ NMR $(500 \mathrm{MHz}$, $\left.\mathrm{CDCl}_{3}\right): \delta 2.36\left(\mathrm{~s}, 3 \mathrm{H}, \mathrm{CH}_{3}\right), 6.39-6.41(\mathrm{~d}, \mathrm{~J}=$ $7.0 \mathrm{~Hz}, 2 \mathrm{H}, \mathrm{Ar}-H), 6.80-7.25$ (m, 4H, Ar-H), 8.37$8.39(\mathrm{~d}, \mathrm{~J}=7.5 \mathrm{~Hz}, 2 \mathrm{H}$, Ar- $H)$; ${ }^{1} \mathrm{H}$ NMR $(125$ $\left.\mathrm{MHz}, \mathrm{CDCl}_{3}\right): \delta 9.7,109.3,110.0,126.1,127.2$, $129.8,159.7,131.3,134.8,148.0,148.9,150.7$,
151.4, 155.2, 160.2; Mass (m/z) : $278\left[\mathrm{M}^{+}\right]$, Anal. Calcd for $\mathrm{C}_{15} \mathrm{H}_{11} \mathrm{~N}_{5} \mathrm{O}: \mathrm{C}, 64.97 ; \mathrm{H}, 4.00 ; \mathrm{N}, 25.26$. Found: C, 64.94; H, 4.02; N, 25.24.

\section{Synthesis of 1-ethyl-4-(pyridin-4-yl)- $[1,2,4]$ triazolo[4,3-a]quinazolin-5(4H)-one (S6)}

Yield: $82 \%$, mp. $302-303{ }^{\circ} \mathrm{C}, \mathrm{IR}(\mathrm{KBr}): 1679$ $(\mathrm{C}=\mathrm{O}), 1629(\mathrm{C}=\mathrm{N}) \mathrm{cm}^{-1},{ }^{1} \mathrm{H}$ NMR $(500 \mathrm{MHz}$, $\left.\mathrm{CDCl}_{3}\right): \delta$ 1.25-1.26 (t, 3H, $\left.\mathrm{CH}_{3}\right), 2.54-2.56(\mathrm{~m}$, $\left.2 \mathrm{H}, \mathrm{CH}_{2}\right), 6.39-6.41(\mathrm{~d}, \mathrm{~J}=7.0 \mathrm{~Hz}, 2 \mathrm{H}, \mathrm{Ar}-\mathrm{H})$, 6.82-7.27 (m, 4H, Ar- $H$ ), 8.54-8.56 (d, J = 7.5 Hz, $2 \mathrm{H}, \operatorname{Ar}-\mathrm{H})$; Mass (m/z): $292\left[\mathrm{M}^{+}\right]$, Anal. Calcd for $\mathrm{C}_{16} \mathrm{H}_{13} \mathrm{~N}_{5} \mathrm{O}: \mathrm{C}, 65.97 ; \mathrm{H}, 4.50 ; \mathrm{N}, 24.04$. Found: C, 65.96; H, 4.48; N, 24.07.

\section{1-propyl-4-(pyridin-4-yl)-[1,2,4]triazolo[4,3- a]quinazolin-5(4H)-one (S7)}

Yield: $83 \%$, mp. $281-282{ }^{\circ} \mathrm{C}$, IR (KBr): 1686 $(\mathrm{C}=\mathrm{O}), 1603(\mathrm{C}=\mathrm{N}) \mathrm{cm}^{-1},{ }^{1} \mathrm{H}$ NMR $(500 \mathrm{MHz}$, $\left.\mathrm{CDCl}_{3}\right): \delta$ 0.82-0.89 (t, 3H, $\left.\mathrm{CH}_{3}\right), 1.72-1.73(\mathrm{~m}$, $\left.2 \mathrm{H}, \mathrm{CH}_{2}\right), 2.45-2.48\left(\mathrm{~m}, 2 \mathrm{H}, \mathrm{CH}_{2}\right), 6.44-6.46(\mathrm{~d}, \mathrm{~J}$ $=7.5 \mathrm{~Hz}, 2 \mathrm{H}, \operatorname{Ar}-H), 6.85-7.28(\mathrm{~m}, 4 \mathrm{H}, \operatorname{Ar}-H)$, 8.43-8.45 (d, J = 8.0 Hz, 2H, Ar- $H$ ); Mass (m/z): $306\left[\mathrm{M}^{+}\right]$, Anal. Calcd for $\mathrm{C}_{17} \mathrm{H}_{15} \mathrm{~N}_{5} \mathrm{O}: \mathrm{C}, 66.87 ; \mathrm{H}$, 4.95; N, 22.94. Found: C, 66.85; H, 4.96; N, 22.96 .

\section{1-(chloromethyl)-4-(pyridin-4-yl)- $[1,2,4]$ triazolo[4,3-a]quinazolin-5(4H)-one (S8)}

Yield: $79 \%$, mp. $293-295{ }^{\circ} \mathrm{C}, \mathrm{IR}(\mathrm{KBr}): 1688$ $(\mathrm{C}=\mathrm{O}), 1606(\mathrm{C}=\mathrm{N}) \mathrm{cm}^{-1},{ }^{1} \mathrm{H}$ NMR $(500 \mathrm{MHz}$, $\left.\mathrm{CDCl}_{3}\right): \delta 4.65\left(\mathrm{~s}, 2 \mathrm{H}, \mathrm{CH}_{2} \mathrm{Cl}\right), 6.43-6.45(\mathrm{~d}, \mathrm{~J}=$ $8.0 \mathrm{~Hz}, 2 \mathrm{H}, \mathrm{Ar}-\mathrm{H}), 7.26-7.68$ (m, 4H, Ar-H), 8.47$8.49(\mathrm{~d}, \mathrm{~J}=8.0 \mathrm{~Hz}, 2 \mathrm{H}$, Ar- $H) ;{ }^{1} \mathrm{H}$ NMR $(125$ $\left.\mathrm{MHz}, \mathrm{CDCl}_{3}\right): \delta 28.7,109.7,110.2,126.4,127.5$, $129.5,161.0,131.7,134.5,148.7,149.6,150.2$, 150.9, 154.6, 159.6; Mass (m/z): $311\left[\mathrm{M}^{+}\right]$, Anal. Calcd for $\mathrm{C}_{15} \mathrm{H}_{10} \mathrm{~N}_{5} \mathrm{OCl}$ : C, 57.79; $\mathrm{H}, 3.23 ; \mathrm{N}$, 22.47. Found: C, 57.78; H, 3.22; N, 22.49.

Thus, all the synthesized compounds were confirmed by spectral data (IR, NMR and mass spectra). Elemental (C, H, N) analysis satisfactorily confirmed elemental composition and purity of the synthesized compounds.

\section{Antihistaminic activity}

Protection against histamine induced bronchospasm on conscious guinea pigs method was adopted to determine the antihistaminic potential of the test compounds. All of them have been found to exhibit significant antihistaminic activity (Table 1). Percentage protection data showed that all test compounds of the series 
Table 1: Antihistaminic and sedative-hypnotic activity of compounds (S4-S8)

\begin{tabular}{|c|c|c|c|c|c|}
\hline \multirow[b]{2}{*}{$\begin{array}{l}\text { Compound } \\
\text { Code }\end{array}$} & \multirow{2}{*}{$\begin{array}{l}\text { Histamine- } \\
\text { induced } \\
\text { bronchospasm } \\
\text { (in Sec) }\end{array}$} & \multirow[b]{2}{*}{$\%$ Protection } & \multicolumn{3}{|c|}{ Percent CNS Depression } \\
\hline & & & $1 \mathrm{~h}$ & $2 \mathrm{~h}$ & $3 \mathrm{~h}$ \\
\hline S4 & $419.00 \pm 4.65^{* *}$ & $71.81 \pm 0.317^{* *}$ & $6.68 \pm 0.19^{\star *}$ & $8.32 \pm 0.13^{\star *}$ & $4.60 \pm 0.16^{* *}$ \\
\hline S5 & $435.00 \pm 4.23^{* *}$ & $72.85 \pm 0.265^{\star *}$ & $8.28 \pm 0.10^{\star *}$ & $9.42 \pm 0.17^{* *}$ & $5.09 \pm 0.10^{* *}$ \\
\hline S6 & $424.83 \pm 5.33^{* *}$ & $72.19 \pm 0.352^{* *}$ & $8.58 \pm 0.09^{* *}$ & $11.17 \pm 0.10^{* *}$ & $5.29 \pm 0.11^{* *}$ \\
\hline s7 & $399.00 \pm 3.87^{* *}$ & $70.40 \pm 0.284^{* *}$ & $9.53 \pm 0.13^{* *}$ & $11.2 \pm 0.09^{* *}$ & $5.16 \pm 0.08^{* *}$ \\
\hline S8 & $386.16 \pm 3.94^{* *}$ & $69.42 \pm 0.315^{\star *}$ & $6.43 \pm 0.26^{\star *}$ & $8.10 \pm 0.09^{* *}$ & $4.67 \pm 0.13^{* *}$ \\
\hline $\begin{array}{l}\text { Chlorphe- } \\
\text { niramine }\end{array}$ & $394.10 \pm 4.43^{*}$ & $70.09 \pm 0.33^{*}$ & $38.80 \pm 1.32^{* *}$ & $34.80 \pm 0.72^{* *}$ & $29.58 \pm 0.72^{* *}$ \\
\hline
\end{tabular}

Each value represents the mean \pm SEM $(n=6)$. Statistical significance: $\left({ }^{* *} p<0.05\right)$

show significant protection in the range of $69-73$ $\%$.

\section{Sedative-hypnotic activity}

As sedation is one of the major side effects associated with antihistamines, the test compounds were also evaluated for their sedative potentials. Sedative-hypnotic activity was determined by measuring the reduction in motor activity. The results of this study (Table 1) showed that almost all the test compounds were found to exhibit mild activity (less than $10 \%$ ).

\section{DISCUSSION}

Structure activity relationship (SAR) studies indicated that different substituents on the C-1, exerted varied biological activity. It has been found that presence of methyl group showed better activity over the unsubstituted compounds. When chain length increased from methyl to ethyl and propyl the activity decreased. Replacement of a proton of the methyl group by chloro showed further decrease in activity. While the order of activity was methyl > ethyl > unsubstituted $>$ propyl $>$ chloromethyl. Among the series, 1-methyl-4-(pyridine-4-yl-[1,2,4] triazolo[4,3-a]quinazolin-5(4H)-one (S5) was the most potent with $72.85 \%$ protection and it is comparable to that of standard chlorpheniramine maleate $(70.09 \%)$. As the test compounds could not be converted to water soluble form, in vitro evaluation for antihistaminic activity could not be performed.

Cetirizine and chlorpheniramine maleate were used as sedative activity references, chlorpheniramine showed nearly $35 \%$ of sedation and cetirizine showed $10-13 \%$ of sedation approximately. Compare to the reference standard choloropheniramine maleate (first generation antihistamine), all the test compounds showed lesser sedative potential; while compare to cetirizine (non-sedative antihistamine) the test compounds showed equipotent sedative activity. Hence this series can be developed as clinically useful nonsedative antihistamines.

\section{CONCLUSION}

A new series of 1-substituted-4-(pyridin-4-yl)$[1,2,4]$ triazolo [4,3-a] quinazolin-5(4H)-ones has been successfully derivatised. These derivatives have exhibited promising antihistaminic activity against histamine-induced bronchospasm on conscious guinea pigs model. Among the series 1-methyl-4-(pyridin-4-yl)-[1,2,4]triazolo[4,3-a] quinazolin-5(4H)-one (S5) was found to be the most active antihistaminic agent, which is more potent (72.85\% protection) than the reference standard chlorpheniramine maleate (70.09\%). Interestingly the sedative property of compound S5 was found to be negligible $(5.09 \%)$ when compared to chlorpheniramine maleate (28.58 $\%$ ), therefore it could serve as a lead molecule for further development into a clinically useful novel class of antihistaminic agents.

\section{REFERENCES}

1. Gordon E, Barrett RW, Dowes WJ, Fodor SP, Gallop MA. Applications of combinatorial technologies to drug discovery. J Med Chem 1994; 37: 1385-1401.

2. Hermakens PHH, Ottenheijm HCJ, Rees DC. Solidphase organic reactions. Part2: A review of the literature November 1995-November 1996. Tetrahedron 1997; 53: 5643-5652.

3. Simons FE, Simons KJ. The pharmacology and use of H1-receptor-antagonist drugs. N Engl J Med 1994; 330: 1663-1670.

4. Ellis EF, Adkinson NF, Yungingen JW, Busso WW. (eds.) Allergy Principles and Practice In Histamine H1receptor antagonists. Mosby-Year Book, Inc, St Louis, 1985, pp 856-891.

5. Carr AA, Meyer DR. Synthesis of terfenadine. Arzneimittelforschung 1982; 32: 1157-1159.

Trop J Pharm Res, February 2015; 14(2): 276 
6. Hopp RJ, Bewtra A, Nair NM, Townley RG. The effect of age on methacholine response. J Allergy Clin Immunol 1985; 76: 609-613.

7. Chairungsrilerd N, Furukawa K, Ohta $T$, Nozoe $S$, Ohizumi Y. Pharmacological properties of alphamangostin, a novel histamine $\mathrm{H} 1$ receptor antagonist. Eur J Pharmacol 1996; 314: 351-356.

8. Mallareddy V, Sattur PB. Chemistry of quinazolinones. Curr Sci 1984; 53: 1069-1075.

9. Mallareddy V, Ravinderreddy P, Jayamma Y. Synthesis and antiinflammatory evaluation of some substituted quinazolinones. Indian Drugs 1987; 25: 182-187.

10. Bartroli J, Turmo E, Alguero M. Synthesis and antifungal activity of 3-substituted-4(3H)-Quinazolinones. J Med Chem 1998; 21: 26-32.

11. Mukherji DD, Nintiyal SR, Prasad CR, Dhawan $B N$. Pharmacological studies on quinazolinones. Ind $\mathrm{J}$ Med Res 1980; 93: 1426-1432.

12. Rao AR, Reddy VM. Synthesis and H1-antihistaminic activity of beta-alkoxyethyl and beta- $(N, N$ dialkylamino)ethyl-(3-aryl-3,4-dihydro-4oxoquinazolin-2-yl)methyl ethers. Pharmazie 1992; 47: 794-796.

13. Buyuktimkin SB, Buyuktimkin N, Ozdemir O, Rollas S. Synthesis of 3-[2-(2,3-dihydro-5-phenyl-4-substituted$3 \mathrm{H}-1,2$, 4-triazole-3-thione-2-yl)-acetylamino]-2methyl-4(3H)-quinazolinones and their pharmacological activities. Arch Pharm 1989; 322: 49-51.

14. Rao AR, Reddy VM. Synthesis of N-heteroaryl-beta-[(2alkoxyethyl)oxy]/beta-[[2-(N,N- dialkylamino)ethyl]oxy]acetamides as possible $\mathrm{H1}$ antihistaminics. J Pharm Sci 1994; 83: 953-955.

15. Alagarsamy $V$, Sharma $H K$, Parthiban $P$, Singh JC, Murugan ST, Solomon VR. 4-(3-Methoxyphenyl)-1substituted-4H-[1,2,4]triazolo[4,3-a]quinazolin-5-ones: new class of H1-antihistaminic agents. Pharmazie. 2009; 64: 5-9.

16. Alagarsamy V, Meena S, Ramaseshu KV, Solomon VR, Kumar TD. 4-Cyclohexyl-1-substituted-4H[1,2,4]triazolo [4,3-a] quinazolin-5-ones: novel class of H1-antihistaminic agents. Chem Biol Drug Des. 2007; 70: 158-63.

17. Alagarsamy V, Solomon VR, Murugan M. Synthesis and pharmacological investigation of novel 4-benzyl-1substituted-4H-[1,2,4]triazolo[4, 3-a]quinazolin-5-ones as new class of H1-antihistaminic agents. Bioorg Med Chem 2007; 15:4009-4015.

18. Van Arman CG, Miller LM and O'Malley MP. SC-10049: a catecholamine bronchodilator and hyperglycemic agent. J Pharmacol Exp Ther 1961; 133:90-97.

19. Committee for the purpose of control and supervision on experiment on animals. CPCSEA guidelines for laboratory animal facility, Indian J Pharmacol 2003; 35: 257- 274.

20. Dews PB. The measurement of the influence of drugs on voluntary activity in mice. Br J Pharmacol 1953; 8:4648.

21. Kuhn WL, Van Maanen EF. Central nervous system effects of thalidomide. J Pharmacol Exp Ther 1961; 134: $60-68$. 